\title{
Countermeasures Against Cervical Cancer Through Detection of Fluor Albus Characteristic in Women at Medan, North Sumatera
}

\section{Fatwa Imelda* and Nurbaiti}

Faculty of Nursing, University of Sumatera Utara

\begin{abstract}
Cervical cancer is the first health problems for women in Indonesia with the highest risk of death. Delay diagnosis in late-stage cancer, vulnerable state, social status, low financial status, limited resource and facilities, type of histopathology and level of education determine patients' prognosis. Fluor Albus is not a type of disease. It is a symptom of disease in female reproductive organs which can cause cervical cancer if it is not treated. Predisposition factors of Fluor Albus are including age, marital status, parity of menstrual cycle, contraception method, history of reproductive disorder, education, and job status. This community service aims to detect characteristic of Fluor Albus and to treat those identified with Fluor Albus atearly stage. The predisposition characteristics of Fluor Albus were collected from anamnesis while the Fluor Albus characteristic data were collected through direct observation of portio state of the uterian cervix. The activity was conducted from July to August 2017 in 3 different areas in Medan, North Sumatra with a total of 40 samples of women in their fertile age. Based on the analysis, 15 respondents $(37.5 \%)$ found to suffer from Fluor Albus. Every woman is expected to be able to have early detection of Fluor Albus or symptoms of inflammatory infection of reproductive organs in order to prevent complication caused by Fluor Albus by paying more attention to personal hygiene, early screening by Pap Smear, IVA, and IHC (Immunohistochemistry).
\end{abstract}

Keywords: Cervical Cancer, Fluor Albus

Abstrak. Kanker serviks merupakan masalah kesehatan perempuan di Indonesia dengan urutan pertama dengan angka kematian yang tinggi. Keterlambatan diagnosis pada stadium lanjut, keadaan yang lemah, status social, ekonomi yang rendah, keterbatasan sumber daya, keterbatasan sarana dan prasarana, jenis histopatologi dan derajat pendidikan ikut dalam menentukan progonis penderita. Flour albous bukan merupakan penyakit melainkan salah satu tanda dan gejala dari suatu penyakit organ reproduksi wanita yang jika tidak ditangani akan mengakibatkan penyakit kanker serviks. factor predisposisi dari flour albous antara

*Corresponding author at: Jalan Prof. T. Maas No. 3 Kampus USU, Padang Bulan, Medan 20155, Indonesia

E-mail address: fatwaimelda05@gmail.com 
lain usia, satus pernikahan, paritas siklus menstruasi, metode kontrasepsi, riwayat gangguan reproduksi, status pemdidikan dan satatus pekerjaan. Kegiatan pengabdian masyarakat ini bertujuan untuk mendeteksi secara dini karakteristik flour albous dan memberikan penanganan secara dini pada penderita flour albous yang teridentifikasi.Pengumpulan data karakteristik predisposisi dari flour albous didapat dari hasil anamnesis dan karakteristik flour albous dengan inspeksi langsung portio dari serviks uteri. Kegiatan ini dilaksanakan dari bulan Juli-Agustus tahun 2017 di lakukan di wilayah di 3 lokasi yang berbeda wilayah Medan Sumatera Utara dengan jumlah sampel sebanyak 40 orang wanita usia subur.hasil dari pengabdian masyarakat ini didapat 15 responden (37.5 \%) menderita flour albous. Diharapkan seluruh wanita dapat mendeteksi secara dini adanya flour albous atau gejala infeksi radang organ reproduksi sehingga dapat mencegah terjadinya komplikasi yang ditimbulkan dari flour albous tersebut dengan lebih memperhatikan personal hygiene, memeriksakan lebih dini dengan Pap smear, IVA dan IHC (Immunohistokimia).

Kata Kunci: Kanker Serviks, Fluor Albus

Received 20 November 2017 | Revised 27 December 2017 | Accepted 13 February 2018

\section{Introduction}

Fluor albus (leukorrhea, white discharge) is the name given to condition where there is another discharge other than blood in vagina. Fluor Albus is the most frequent found symptom in gynecologic patients because it is dirtying their undergarments. Physiologic and pathologic Fluor Albus can be differed. Physiologic Fluor Albus is a liquid which is sometimes mucus which contains many epithel and rarely found leukocytes whereas pathologic Fluor Albus contains many leukocytes [1]. Fluor Albus is manifestation of several reproduction infections, deadly or undeadly tumour. In cervical cancer, Fluor Albus is significantly different from the one discharged in normal condition. The characteristic of women with Fluor Albus are age, marital status, parity, contraception method, menstrual cycle, history of reproductive disorder, educational level, and job status [2].

Physiological Fluor Albus is at risk to become pathological if it is not treated. Therefore, it is important to have habitual change to keep intimate organ to stay dry and not humid [3]. Fluor Albus can cause adhesion in the wombs and fallopian tube until the ovary decays due to heavy infection which then leads to tuba-ovarian abscess or a sacofpus which press onto the fallopian tube. When both right and left side of ovarian tubes are pressed, a woman will not be able to have an offspring or is infertile [4].

Pathological fluor albus can indicate a more serious symptom, such as cervical cancer. Besides having a different colour, Fluor Albus from cervical cancer symptom has a foul smell; stink and fishy. Another symptom is itchiness in the vaginal area. Fluor Albus is a form of protection inside 
the body to fight HPV virus which is the cause of Fluor Albus in cervical cancer. However, the liquid discharge has to work extra hard to give protection from other things, such as virus and other attacks. In the end, fluor albus liquid goes through inability, and eventually it only sends signals. The development of cancer cell differs in each stage. The less treatment and prevention done, the quicker cancer cells will spread.

\section{Method}

The community service was conducted by anamnesis of predisposition from age, marital status, parity of menstrual cycle, contraception method, history of reproductive disorder, education and job status and also by doing internal test which is a direct observation to portio state of the uterine cervix for fertile women in Medan, North Sumatra. Finally, counseling to raise awareness of further examination including PAPSMEAR, IVA and IHC (immunohistochemistry), and antibiotics were given to those detected with fluor albus. All activities involved the community service members, doctors, medical students, and medical staffs in the location. This community service aims to detect characteristic of Fluor Albus and to treat those identified with Fluor Albus at early stage. The service had been conducted for 2 months from July to August. At first, the team prepared all tools needed for Fluor Albus examination using direct observation of portio state of the uterin cervix. The tools used were gynecologist bed, lights, and blankets while the one-time used materials were disposable speculum set, handscoon, mask, object glass, liquid betadine, medical cotton, and jelly.

\section{Results and Discussion}

\subsection{Characteristic of women with fluor albus based on age}

Table 1 shows that most respondents $(72.5 \%)$ were more than 35 years old ageand $37.5 \%$ of them were fluor albus positive. Reproduction in adult females aged 35 years and above undergo aging process. The theory explains that premenarche and postmenopause ages are one of the risk factors which can increase the incident of Fluor Albus [5]. In general, mucosa cells are only matured after women are above 20 years old. Therefore, if a woman has sexual relationship in adolescence, it is more prone for a woman under 16 years old. This is related to the maturity of mucosa cells in cervix. In early age, the mucosa cells in cervix are not yet mature which means that it is susceptible to stimulation and not ready to accept external stimulation, including chemicals from sperms. As a result, mucosa cells can transform to be a cancer. However, if intercourse is done at 20 years old or above, mucosa cells are no longer vulnerable to change. 
Table 1. Frequency distribution of women with Fluor Albus in Medan, North Sumatera based on age

\begin{tabular}{ccccccc}
\hline $\begin{array}{c}\text { Age } \\
\text { (years old) }\end{array}$ & Frequency & Percentage & $\begin{array}{c}\text { Normal } \\
\text { frequency }\end{array}$ & $\begin{array}{c}\text { Normal } \\
\text { percentage }\end{array}$ & $\begin{array}{c}\text { Fluor } \\
\text { Albus }\end{array}$ & $\begin{array}{c}\text { Fluor albus } \\
\text { percentage }\end{array}$ \\
\hline$<20$ & 0 & 0 & 0 & 0 & 0 & 0 \\
$20-35$ & 8 & 20 & 3 & 7.5 & 5 & 12.5 \\
$>35$ & 32 & 80 & 17 & 42.5 & 15 & 37.5 \\
\hline
\end{tabular}

\subsection{Characteristic of women with fluor albus based on marital status}

Table 2 shows that the majority of respondents (97.5\%) were married with $35 \%$ of them were Fluor Albus positive. The result of this community service is that marriage increases the risk of Fluor Albus. This is in accordance with the theory stating that married women are at more risk of Fluor Albus due to sexual behaviour. Physiology Fluor Albus can be found before and after sexual intercourse, as well as in ovulation. During sexual activity, germs can enter female reproduction organ which can cause infection [6]. Fluor Albus due to cervical cancer can be caused by having different sexual partners frequently or transmitted from husband to wife which is followed by bleeding while having sex. This usually shows second or third stage [7]. Women who are sexually active in 20 - 35 years old and HPV infected will suffer from cervical cancer in $10-20$ years period. Then, women who marry before the age of 20 are also at risk because reproduction organ is yet ready for sexual intercourse at young age [8].

Table 2. Frequency distribution of women with Fluor Albus in Medan, North Sumatra based on marital status

\begin{tabular}{lcccccc}
\hline $\begin{array}{l}\text { Marital } \\
\text { Status }\end{array}$ & Frequency & Percentage & $\begin{array}{c}\text { Normal } \\
\text { frequency }\end{array}$ & $\begin{array}{c}\text { Normal } \\
\text { percentage }\end{array}$ & $\begin{array}{c}\text { Fluor } \\
\text { Albus }\end{array}$ & $\begin{array}{c}\text { Fluor Albus } \\
\text { percentage }\end{array}$ \\
\hline Married & 39 & 97.5 & 25 & 62.5 & 14 & 35 \\
$\begin{array}{l}\text { Divorce/ } \\
\text { widow }\end{array}$ & 1 & 2.5 & 0 & 0 & 1 & 2.5 \\
\hline
\end{tabular}

\subsection{Characteristic of women with Fluor Albus based on education status}

Table 3 shows that half of the female respondents (50\%) were senior high school graduates and $22.5 \%$ of them were Fluor Albus positive. The acceptance of new behaviour is easier if it is based on the right knowledge, self awareness, and positive attitude [9]. Having more knowledge does not always lead to behaviour changes. Lack of knowledge causes low perineal hygiene. As a result, Fluor Albus case increases. Low understanding about vaginal hygiene, having no right attitude in keeping cleanliness, and lack of shared information have resulted in lack of new information. Therefore, vaginal hygiene behaviour depends to the surrounding [10]. 
Table 3. Frequency distribution of women with Fluor Albus in Medan, North Sumatra based on education degree

\begin{tabular}{lcccccc}
\hline $\begin{array}{l}\text { Education } \\
\text { degree }\end{array}$ & Frequency & Percentage & $\begin{array}{c}\text { Normal } \\
\text { frequency }\end{array}$ & $\begin{array}{c}\text { Normal } \\
\text { percentage }\end{array}$ & $\begin{array}{c}\text { Fluor } \\
\text { Albus }\end{array}$ & $\begin{array}{c}\text { Fluor Albus } \\
\text { percentage }\end{array}$ \\
\hline SLTA & 20 & 50 & 11 & 27.5 & 9 & 22.5 \\
Diploma & 7 & 17.5 & 4 & 10 & 3 & 7.5 \\
$\begin{array}{l}\text { Under-grad } \\
\text { uate }\end{array}$ & 13 & 32.5 & 10 & 25 & 3 & 7.5 \\
\hline
\end{tabular}

\subsection{Characteristic of women with Fluor Albus based on job status}

Table 4 shows that over half of the female respondents (67.5\%) were unemployed and $27.5 \%$ of them were Fluor Albus positive. Income factor is related to nutrition and immunity. Low income group usually has low quantity and quality food which affect body immune system. There is a strong relationship between cervical cancer and low economy status. Low income group usually has no access to good health service which includes pap smear test which is compulsory for women aged 35 years and above. Women with low income do not usually pay attention to nutrition consumed and immunity. Income highly affects cervical cancer case. Individual hygiene, sanitation, and good health care are difficult to have by the low income group.

Table 4. Frequency distribution of women with Fluor Albus in Medan, North Sumatera based

\begin{tabular}{lcccccc}
\hline Job status & Frequency & Percentage & $\begin{array}{c}\text { Normal } \\
\text { frequency }\end{array}$ & $\begin{array}{c}\text { Normal } \\
\text { percentage }\end{array}$ & $\begin{array}{c}\text { Fluor } \\
\text { Albus }\end{array}$ & $\begin{array}{c}\text { Fluor } \\
\text { Albus } \\
\text { percentage }\end{array}$ \\
\hline Employed & 13 & 22.5 & 9 & 22.5 & 4 & 10 \\
Unemployed & 27 & 67.5 & 16 & 40 & 11 & 27.5 \\
\hline
\end{tabular}

\subsection{Characteristic of women with Fluor Albus based on parity}

Table 5 shows that history of parity had equal distribution, $\leq 2$ and $>2$. There were $50 \%$ of total respondents with parity status and $27.5 \%$ of them were Fluor Albus positive in $\leq 2$ parity history. Based on a research conducted by Hidayat [11], >3 parity was 16.03 times more at a risk of cervical cancer than those with a total parity of $<3$. Women with high parity are associated with eversion of columnar epithelium cervix during pregnancy which causes new dynamic in immature metaplastic epithelium. As a result, cell transformation and trauma in cervix increase and HPV infection is more likely to happen [12]. Hormonal change during pregnancy might make women become more susceptible to HPV virus or cancer growth. 
Table 5. Frequency distribution of women with Fluor Albus in Medan, North Sumatera based on parity

\begin{tabular}{ccccccc}
\hline $\begin{array}{c}\text { Parity } \\
\text { history }\end{array}$ & Frequency & Percentage & $\begin{array}{c}\text { Normal } \\
\text { frequency }\end{array}$ & $\begin{array}{c}\text { Normal } \\
\text { percentage }\end{array}$ & $\begin{array}{c}\text { Fluor } \\
\text { Albus }\end{array}$ & $\begin{array}{c}\text { Fluor Albus } \\
\text { percentage }\end{array}$ \\
\hline$\leq 2$ & 20 & 50 & 9 & 22.5 & 11 & 27.5 \\
$>2$ & 20 & 50 & 16 & 40 & 4 & 10 \\
\hline
\end{tabular}

\subsection{Characteristic of women with Fluor Albus based on menstrual cycle}

Table 6 shows that most respondents $(62.5 \%)$ had a regular menstrual cycle and $22.5 \%$ of them were Fluor Albus positive. Among 40 respondents assessed, 22.5\% had a regular menstrual cycle and $12.5 \%$ of them had irregular menstrual cycle. Irregular menstruation is caused by imbalance hormones. Changes in hormones during menstruation period, stress, pregnancy, and the use of contraception can lead to Fluor Albus.

Table 6. Frequency distribution of women with Fluor Albus in Medan, North Sumatera based on menstrual cycle

\begin{tabular}{lcccccc}
\hline \multicolumn{1}{c}{$\begin{array}{c}\text { Menstrual } \\
\text { cycle }\end{array}$} & Frequency & Percentage & $\begin{array}{c}\text { Normal } \\
\text { frequency }\end{array}$ & $\begin{array}{c}\text { Normal } \\
\text { percentage }\end{array}$ & $\begin{array}{c}\text { Fluor } \\
\text { Albus }\end{array}$ & $\begin{array}{c}\text { Fluor Albus } \\
\text { percentage }\end{array}$ \\
\hline Regular & 25 & 62.5 & 16 & 40 & 9 & 22.5 \\
Irregular & 12 & 30 & 7 & 17.5 & 5 & 12.5 \\
$\begin{array}{l}\text { No } \\
\text { menstruation }\end{array}$ & 3 & 7.5 & 2 & 5 & 1 & 2.5 \\
\hline
\end{tabular}

\subsection{Characteristic of women with Fluor Albus based on contraception}

Table 7 shows that majority of respondents (75\%) had no history in family planning (KB) with $27.5 \%$ of them were Fluor Albus positive. The consumption of family-planning-purposed pills, which contain progesterone and estrogen, can give negative effect to the wombs. There will be infection in the wombs and women might suffer from cervical cancer [13]. It can be concluded that the use of contraception influenced Fluor Albus. Oral contraception with high estrogen level causes adhesiveness of Candida albicans which is the bacteria causing Fluor Albus. Candida albicans can cause adhesiveness in vagina epithelium and become the media for fungus growth. It grows well in the environment withpH 5-6.5. The changes can be asymptomatic or until infection starts. 
Table 7. Frequency distribution of women with Fluor Albus in Medan, North Sumatera based on contraception for family planning program

\begin{tabular}{lcccccc}
\hline \multicolumn{1}{c}{$\begin{array}{c}\text { History of } \\
\text { contraception } \\
\text { product }\end{array}$} & Frequency & Percentage & $\begin{array}{c}\text { Normal } \\
\text { frequency }\end{array}$ & $\begin{array}{c}\text { Normal } \\
\text { percentage }\end{array}$ & $\begin{array}{c}\text { Fluor } \\
\text { Albus }\end{array}$ & $\begin{array}{c}\text { Fluor Albus } \\
\text { percentage }\end{array}$ \\
\hline $\begin{array}{l}\text { Hormonal } \\
\text { contraception }\end{array}$ & 5 & 12.5 & 3 & 7.5 & 2 & 5 \\
$\begin{array}{l}\text { Simple } \\
\text { contraception }\end{array}$ & 0 & 0 & 0 & 0 & 0 & 0 \\
$\begin{array}{l}\text { IUD } \\
\text { Mantap }\end{array}$ & 3 & 7.5 & 2 & 5 & 1 & 2.5 \\
contraception & 2 & 5 & 1 & 2.5 & 1 & 2.5 \\
$\begin{array}{l}\text { No } \\
\text { contraception }\end{array}$ & 30 & 75 & 19 & 47.5 & 11 & 27.5 \\
used & & & & & & \\
\hline
\end{tabular}

\section{Conclusion}

$72.5 \%$ of respondents were in the age group of 35 years old and above with $37.5 \%$ of them were Fluor Albus positive. Nearly all respondents were married and 35\% among them were Fluor Albus positive. Half of the respondents were senior high school graduates with $22.5 \%$ of them were Fluor Albus positive. $67.5 \%$ of the total respondents were married with $27.5 \%$ of them were Fluor Albus positive. History of parity had equal distribution, $\leq 2$ and $>2$. There were $50 \%$ of total respondents with parity status and $27.5 \%$ of them were Fluor Albus positive in $\leq 2$ parity history. $62.5 \%$ of respondents hada regular menstrual cycle with $22.5 \%$ of them were Fluor Albus positive $.75 \%$ of respondents had no history of family planning $(\mathrm{KB})$ with $27.5 \%$ of them were Fluor Albus positive.

\section{References}

[1] Amiruddin, D. Fluor Albus in Penyakit Menular Seksual. 2003.LKiS : Jogjakarta.

[2] Khuzaiyah, S., Krisiyanti, S., and Cristi, I. 2015. Jurnal Ilmiah Kesehatan VII (1).

[3] Wijayanti D, 2009. Fakta Penting Seputar Kesehatan Reproduksi Wanita. Book Marks. Jojakarta.

[5] Baradero, M. 2007. Klien Gangguan Sistem Reproduksi dan Seksualitas, EGC. Jakarta.

[6] Lisnawati, 2013.Asuhan Kebidanan terkini Kegawatan Maternal dan Neonatal. Tran Info Media, Jakarta.

[7] Martiastutik, 2008, Buku Ajar Infeksi Menular Seksual.Airlangga University Press. Surabaya.

[8] Brunner. S, Keperawatan Medikal Bedah. Jakarta : EGC: 2001.

[9] Notoatmodjo, S.2012. Ilmu Perilaku Kesehatan. Jakarta : Rineka Cipta. 
[10] Nurhayati, A. 2013. Hubungan Pengetahuan Sikap dan Perilaku Vaginal Hiegine terhadap Kejadian Keputihan Patologis pada Remaja Putri Usia 13-17 Tahun di daerah Pondok Cabe Ilir. Karya Tulis Ilmiah Stata Satu, Universitas Islam Negeri Syarif Hidayatullah, Jakarta.

[11] Hidayat, E, Hasibuan, D.H.S, Fitriyati, Y, 2014. JKKI, Vol. 6, No.3, September-Desember 2014

[12] Center for Disease Control and Prevention Human Papillomavirus-Associated Cancer United State. 2004-2008, MMWR Morb Mortal Wkly Rep 201261 (15); 258-261

[13] Wahyuningsih, T. and Mulyani, E.Y. 2014. Factor Resiko Terjadinya Lesi Prakanker Serviks Melalui Deteksi Dini dengan Metode IVA (inspeksi Visual Asam Asetat).Forum Ilmiah. 11 (2):192-209 